\title{
LARGE-SCALE, POLYMERASE CHAIN REACTION-BASED SURVEILLANCE OF SCHISTOSOMA HAEMATOBIUM DNA IN SNAILS FROM TRANSMISSION SITES IN COASTAL KENYA: A NEW TOOL FOR STUDYING THE DYNAMICS OF SNAIL INFECTION
}

\author{
JOSEPH HAMBURGER, ORIT HOFFMAN, H. CURTIS KARIUKI, ERIC M. MUCHIRI, JOHN H. OUMA, \\ DAVY K. KOECH, ROBERT F. STURROCK, AND CHARLES H. KING \\ Kuvin Center, Hebrew University, Hadassah Medical School, Jerusalem, Israel; Division of Vector Borne Diseases, Ministry of \\ Health, Nairobi, Kenya; Kenya Medical Research Institute, Nairobi, Kenya; London School of Hygiene and Tropical Medicine, \\ London, United Kingdom; Center for Global Health and Diseases, Case Western Reserve University, School of Medicine, \\ Cleveland, Ohio
}

\begin{abstract}
Levels of prepatent Schistosoma haematobium infection were monitored in intermediate host snails (Bulinus nasutus) collected from transmission sites in coastal Kenya, using a polymerase chain reaction (PCR) assay amplifying the Dra I repeated sequence of $S$. haematobium. The timing and number of prepatent and patent infections were determined for each site and, where the time of first appearance was clear, the minimal prepatent period was estimated to be five weeks. High, persistent, prepatency rates (range $=28-54 \%$ ), indicated a significant degree of repeated area contamination with parasite ova. In contrast, rates of cercarial shedding proved locally variable, and were either low (range $=0.14-3.4 \%$ ) or altogether absent, indicating that only a small proportion of infected snails reach the stage of cercarial shedding. Given the apparently strong focal effects of environmental conditions, implications of these new data are discussed regarding the estimation of local force of transmission and the design of control activities.
\end{abstract}

\section{INTRODUCTION}

Schistosomiasis transmission is affected by a variety of factors, including rates of human contact with transmitting water bodies, the proliferation of intermediate host snails within these water bodies, and the rate of successful entry and development of schistosome stages in both molluscan and human hosts. ${ }^{1}$ At present, the tools for estimating schistosomiasis transmission potential focus on monitoring the components of the human-snail-water interface, where transmission occurs. Surveillance techniques include monitoring schistosome egg output by humans, ${ }^{2}$ human water contact activities, ${ }^{3,4}$ snail infection rates, ${ }^{5,6}$ and, in some cases, numbers of cercariae in the water. ${ }^{5,7}$ However, the effective level of water-contamination with schistosome ova, which culminates in the infection of host-snails by miracidia, has not yet been directly determined.

Measurement of infection rates in field populations of snails is a mainstay of studies on the epidemiology of schistosomiasis. ${ }^{8}$ The data obtained can facilitate planning of schistosomiasis control and the assessment of its outcomes. ${ }^{9}$ Data on snail infection rates can also be used for mathematical modeling of schistosome transmission. ${ }^{10}$ However, fieldsnail infection rates are routinely measured only by determining the rate of snails shedding cercariae, while the rate of prepatent infections is left unmonitored. ${ }^{11}$ Considering that prepatent infection can last for several weeks with only a proportion of snails reaching the stage of cercarial shedding, ${ }^{12,13}$ that mortality of infected snails can be higher after cercarial shedding, ${ }^{14,15}$ and that in cold seasons sporocyst development is delayed, ${ }^{16}$ it can be assumed that prepatent infection rates can be substantial, and will variably exceed patent infection rates over time. ${ }^{17}$ These points have been used to explain discrepancies between the snail infection rates predicted by theory and those observed in the field. ${ }^{18-20}$ However, detailed data on prepatency in field snails have not been available because the available detection methods, including snail crushing in search of larvae and repeated shedding in the laboratory, ${ }^{21}$ are unsuitable for accurate and large-scale monitoring.

We have previously identified prepatent infections by detecting schistosomal antigens in snail hemolymph, ${ }^{22,23}$ but as with previous methods, very early prepatent infections, perhaps the most relevant outcome for linking snail infection to water contamination, could not be detected. A new tool was required for determining the rate of prepatent infections at transmission sites from very early infection onward. Wider coverage for detection of prepatency would logically better capture the summation of factors affecting water contamination by schistosome ova and the subsequent accessibility and infectivity of miracidia. Potentially, it could be used to evaluate the factors that affect local snail infection, including the intensity of infection in human populations using the site.

We have recently developed a polymerase chain reaction (PCR) assay amplifying a highly abundant, tandemly repeated DNA sequence of Schistosoma mansoni for detecting infection of Biomphalaria species snails throughout prepatency. ${ }^{24,25}$ We have now further identified a tandemly repeated DNA sequence, termed Dra I, in the genome of $S$. haematobium, and demonstrated that a highly sensitive PCR assay amplifying this sequence can easily detect individual cercariae. ${ }^{26}$ In the present study, we adapted this Dra I assay for large-scale monitoring of field snails to provide yearround observation of prepatent $S$. haematobium infections in snails recovered from transmission sites in the Msambweni area of the Kwale District of the Coast Province of Kenya. ${ }^{27}$ This approach enabled large-scale monitoring of snail infection prevalence throughout prepatency, and allowed, for the first time, quantitative estimation of human-to-snail schistosomiasis transmission.

\section{POPULATIONS, MATERIALS, AND METHODS}

Study area. The study area consists of a $25-\mathrm{km}^{2}$ section, centered on coordinates $4^{\circ} 28^{\prime} \mathrm{S}, 39^{\circ} 28^{\prime} \mathrm{E}$, in the Msambweni area of the Kwale District of the Coast Province of Kenya. Details of the study area have been described elsewhere. ${ }^{27-30}$ 
Briefly, this area is rural, and is used primarily for small-hold farming. It includes 10 villages with loosely clustered houses. Areas of cultivated land (shambas) are interspersed with plantations of bananas or coconut, mango, citrus, kapok, or cashew nut trees. Most area residents are involved in subsistence agriculture, with limited rice farming, supplemented by fishing, and goat and cattle raising. Standpipe taps or borehole wells are available in some areas, but most residents depend on natural water sources. Soil from the study area consists of sandy loams overlying limestone and coral rock. Along a former course of the Mukurumudzi River, local depressions have accumulated a fine, impervious silt that permits accumulation of water in series of pools (or dams) ranging in diameter from a few meters to approximately $0.5 \mathrm{~km}$. The pools support true aquatic plants, including water lilies, as well as intrusive marginal sedges and other vegetation. Water levels fluctuate considerably with rainfall, and all but the largest pools dry out during prolonged droughts.

Water-bodies and water-contact sites. The water bodies and transmission sites concerned have been described in a previous report. ${ }^{31}$ Survey sites were selected, on the basis of preliminary field observations, as obvious and discrete water contact points where people consistently go to collect water, wash clothes, bathe, or play. Briefly, sites 1-4 are at Kiziamkala dam, sites 5-7 at Maridzani dam, site 8 at Bovo pool, sites 9-13 at Nimbodze dam, sites 14-16 at Mwachiangwa dam, sites 17-19 at Mwamagongo dam, site 20 is a rice field, and sites 23 and 24 are on Lukungwi Stream. Control sites 21 and 22 at the Mkurumji River did not yield any host snails, and at Mwachiangwa dam, sites 14-16, only one host-snail was found throughout the study period. Data on water conditions (including $\mathrm{pH}$, temperature, turbidity, and conductivity), and vegetation (abundance and type) were recorded at each site once a month. ${ }^{31}$ Monthly rainfall records were obtained from an agricultural station near the study site.

Ethical oversight. After obtaining informed consent from area residents (or from their parents for children), human water use activities were monitored and egg materials recovered under human investigations protocols reviewed and approved by the Ethical Review Board of Kenya Medical Research Institute (Nairobi, Kenya) and by the Human Investigations Review Board of University Hospitals (Cleveland, $\mathrm{OH})$. Standard praziquantel therapy $(40 \mathrm{mg} / \mathrm{kg})$ was given to all human subjects found to be infected with $S$. haematobium.

Field sampling methods. Field snails (both host and nonhost snails) were collected every two weeks or weekly during 2001 from the 24 sites described earlier in this report. The host snail species, Bulinus nasutus, was identified by one of the co-authors (Hoffman $\mathrm{O}$ and others, unpublished data). Sampling of snail populations was carried out by trained local workers from the Division of Vector Borne Disease, Ministry of Health (Kenya). Snails were collected by timed five-minute searches of defined areas ${ }^{32}$ using a standard snail scoop. ${ }^{7,33}$ Recovered snails were transported to the base laboratory, rinsed, and individually exposed to sunlight or bright artificial light for several hours in glass tubes containing filtered pond water with visual and microscopic checks for cercarial shedding. ${ }^{30}$ The type of cercariae was confirmed by a supervisor using a hand lens or dissecting microscope. Snails designated for PCR testing (non-shedding snails, shedders of non-S. haematobium cercariae, and a sample of S. haematobium- shedding snails) were routinely preserved in $70 \%$ ethanol until processed.

Polymerase chain reaction detection of $\boldsymbol{S}$. haematobiuminfected snails. Extraction of DNA. Two different methods were used for extracting DNA from snails. The $\mathrm{NaOH}$ extraction method was previously described by Hamburger and others. ${ }^{24}$ Briefly, each snail (including the shell) was triturated vigorously with $300 \mu \mathrm{L}$ of $1 \mathrm{M} \mathrm{NaOH}$ plus $1 \%$ Triton $\mathrm{X}-100$. The homogenate was left at room temperature for three days, then neutralized with $\mathrm{HCl}$, boiled for 15 minutes, cooled quickly on ice for five minutes, and centrifuged at $10,000 \mathrm{rpm}$ for 15 minutes to remove debris. The supernatants were collected, DNA was precipitated by ethanol, and the pellet was washed with cold $70 \%$ ethanol and dissolved in 100 $\mu \mathrm{L}$ of TE buffer (10 mM Tris, $1 \mathrm{mM}$ EDTA, $\mathrm{pH} 8.0)$ and stored at $-20^{\circ} \mathrm{C}$ until used.

The alternate hexadeclytrimethylammonium bromide (CTAB) extraction method, which proved equally sensitive but less complex to perform, was carried out as previously described by Stothard and others ${ }^{34}$ with some modifications. Snail bodies were removed from their shell and incubated in $0.6 \mathrm{~mL}$ of lysis buffer (100 mM Tris base, $20 \mathrm{mM}$ EDTA, 1.4 $\mathrm{M} \mathrm{NaCl}, 2 \% \mathrm{CTAB}, 0.2 \%$ 2-mercaptoethanol) and proteinase K. For snails with a shell length $\leq 0.5 \mathrm{~cm}, 0.2 \mathrm{mg}$ of proteinase $\mathrm{K}$ was used, and for snails with shells $>0.5 \mathrm{~cm}, 0.4$ $\mathrm{mg}$ of proteinase $\mathrm{K}$ was used. Following incubation for three hours at $60^{\circ} \mathrm{C}$, nucleic acids were extracted twice using chloroform/isoamyl alcohol, followed by precipitation with ethanol. The pellet was washed with cold $70 \%$ ethanol to remove excess salts and dissolved in $100 \mu \mathrm{L}$ of TE buffer.

Amplification by PCR. This was carried out in a total volume of $50 \mu \mathrm{L}$ containing $200 \mu \mathrm{M}$ of each dNTPs, $20 \mathrm{pM}$ of the two amplification primers, 2.5 units of Taq polymerase (Red Hot Taq; Advanced Biotechnologies, Epsom, United Kingdom), and $5 \mu \mathrm{L}$ of DNA. For DNA recovered by $\mathrm{NaOH}$ extraction, we used $10 \mathrm{mM}$ Tris- $\mathrm{HCl}, \mathrm{pH} 8.3,2.5 \mathrm{mM} \mathrm{KCl}, 1.5$ $\mathrm{mM} \mathrm{MgCl} 2$. For DNA recovered by CTAB extraction, we used $10 \mathrm{mM}$ Tris- $\mathrm{HCl}, \mathrm{pH} 9.2,3.5 \mathrm{mM} \mathrm{KCl}, 7.5 \mathrm{mM} \mathrm{MgCl}_{2}$. The nested primers, designed based on the 121-basepair highly repeated sequence of $S$. haematobium, ${ }^{26}$ were $5^{\prime}$ GATCTCACCTATCAGACGAAAC-3' and 5' TCACAACGATACGACCAAC- $3^{\prime}$. The amplification was carried out in a DNA thermal cycler (MiniCycler; MJ Research, Watertown, MA). The reaction mixtures were initially heated at $94^{\circ} \mathrm{C}$ for 5 minutes and were then subjected to 35 cycles of $95^{\circ} \mathrm{C}$ for 1 minute, $60^{\circ} \mathrm{C}$ for 1 minute, and $72^{\circ} \mathrm{C}$ for 30 seconds. A final elongation step at $72^{\circ} \mathrm{C}$ for 10 minutes was performed. Resulting PCR products were detected by standard gel electrophoresis. ${ }^{26}$

Assay sensitivity and specificity. When purified S. haematobium DNA was added to uninfected whole snails, then subjected to the DNA extraction steps outlined earlier, the results of PCR testing were positive when DNA was added at levels $\geq 100 \mathrm{fg}$ per sample, suggesting an comparable high level of sensitivity for DNA detection in the infected field snails. Additional studies confirmed that the addition of a single $S$. haematobium cercaria to an uninfected snail body, prior to DNA extraction, reliably resulted in a positive PCR signal.

Preliminary studies demonstrated the total absence of a PCR signal from control, uninfected, laboratory-reared $B$. $n a$ sutus snails $(\mathrm{n}=50)$ and from field snails shedding non- 
schistosome cercariae. Testing for schistosome species specificity has previously indicated Dra I cross-hybridization on a dot-blot with purified DNA of other Schistosoma having terminal-spined ova ( $S$. mattheei, $S$. margrebowiei, S. bovis, $S$. curassoni, and $S$. intercalatum), but not other trematodes, particularly S. mansoni, Trichobilharzia, and Echinostoma. ${ }^{26} \mathrm{On}$ routine surveillance, the other terminal-spined egg (crossreacting) Schistosoma species were not observed the study area. Due to the unavailability of snails infected with these cross-reacting species, we are presently unable to determine the full level of assay specificity in field snail specimens.

Sampling strategy for PCR testing of field snails. The snails sent for PCR testing were collected from the transmission sites and found negative for patent Schistosoma-type cercariae (after exposure to light on two consecutive days), but included those shedding non-Schistosoma type cercariae. When positive, their PCR results could be combined with the shedding results to provide a profile of the abundance of total infected snails versus infectious/shedding snails at each study site. Several snails shedding S. haematobium cercariae (positive controls) were also tested. Because snail recovery at a given site was sometimes quite high ( $>100$ snails/site/month), PCR positivity rates for that site were estimated by testing a large $(25-50 \%)$ haphazard sub-sample of the non-shedding snails recovered from such locations during that period. When fewer snails were sent from a site, two-thirds or more of the snails were tested. For most monthly snail collections, more than $50 \%$ of the snails collected were tested by PCR.

Determining prepatent infection, patent infection, and mortality rates among laboratory-bred control snails. For comparison with results obtained in field-caught snails, a series of control studies was performed with laboratory-bred, laboratory-reared, infected Bulinus snail lines that were derived from progenitor specimens taken from the study area. All snails used for this phase of the study were from first- to fourth-generation stocks derived from these field collected $B$. nasutus (Kariuki HC and others, unpublished data). For laboratory infection studies, snails were individually exposed to miracidia of S. haematobium hatched from eggs collected from Kwale District at a rate of five miracidia/snail. To obtain miracidia, eggs were washed-filtered in normal saline using a specially designed filtration apparatus, similar to the one previously described by Browne and Thomas, ${ }^{35}$ and hatched by exposure to fresh water. In two experiments, snails exposed to miracidia were kept in the laboratory under optimal conditions. Then, at appropriate times up to day 70, sample snails were harvested into $70 \%$ ethanol for testing by PCR. In a separate experiment, snails were exposed to five miracidia/ snail and kept in the laboratory under optimal conditions and examined daily for cercarial shedding and mortality until all snails died. Shedding was monitored daily by exposing the snails to artificial light for 1.5 hours. Shedders were color marked to enable following the duration of shedding and time of death. Survival of infected snails was then compared with that of a parallel control group of unexposed snails, and all dead exposed snails were tested for persistent PCR positivity.

\section{RESULTS}

Type of sites according to presence of snail populations. The 24 field sites in the study area varied significantly over time in the abundance of B. nasutus snails. River sites 21 and 22 did not yield host snails at any time, and sites 14-16 at Mwachiangwa dam yielded only one or two host snails each throughout the study period (February through December 2001). Therefore, these sites are not considered further in the analysis.

As presented in Figures 1 and 2A, the remainder of the sites fell into two main categories with regard to the presence of snail populations.

Seasonal (temporary) pond or stream sites. These sites exhibited snail populations for 5-6 months, with both clear onset and termination of snail detection, and were suitable for following the seasonal dynamics of temporary snail populations and their prevalence of $S$. haematobium infection. As these sites became active, when the monsoonal rains began, prepatent snail infection (PCR positivity) was noted very soon after the first snails were detected. Shedding snails (patent infections) appeared later at some of these sites, approximately 2-14 weeks after onset of stable snail detection at the pools. As summarized in Figure 1, these sites were sites 1-4 at Kiziamkala dam, site 8 at Bovo pool, sites 17-19 at Mwamagongo dam, site 20, a rice field, and sites 23 and 24 at Lukungwi Stream.

Perennial ponds. In these sites, snails were found for most of the year, given typical rainfall, although the sites could dry completely during severe drought (as occurred in 2002-2003). This category included sites 5-7 at Maridzani dam and sites 9-13 at Nimbodze dam). A brief termination (lasting 1-3 months) and then the restart of snail detection was noted at Nimbodze sites 9-11 (Figures 1 and 2A).

Size of snail populations. Figure $2 \mathrm{~A}$ presents the cumulative monthly numbers of snails collected and tested for shedding, and of those taken for PCR, as well as the corresponding rates of snails with prepatent (PCR positive) and patent infections. The results indicate that at temporary sites, snail numbers began to increase after the peak of the long rainy season, at a time when daily rainfall started to subside (June-July). In contrast, snail numbers decreased as pools receded and water conductivity went up from October through December. ${ }^{31}$ At perennial sites, conductivity and snail detection were largely stable throughout the study period, yet at sites 9-11, a brief termination of the presence of snails was noted (Figures 1 and 2A). At most sites, total snail numbers over the study period were in the hundreds up to $>1,000$. The sites with lowest numbers of snails collected were sites 23 and 24 at Lukungwi Stream, which had only 15 and 43 total B. nasutus snails collected, respectively. Sites 3 and 4, two of the four surveillance sites located at Maridzani dam, had only 74 and 75 total $B$. nasutus, respectively. The population of snails sampled for PCR averaged $49 \%$ of the cumulative number of snails collected per month. Overall, $155 \mathrm{cu}-$ mulative monthly snail collections were recorded in the 19 sites considered in the present study. Snail samples taken for the PCR in 149 of the cases were $>20 \%$ of the snails collected, in 138 of the cases $>40 \%$ of the snails collected, and in 108 of the cases $>50 \%$ of the snails collected.

Polymerase chain reaction positivity, cercarial shedding, and viability of laboratory-bred infected snails. A series of experiments was performed using laboratory-bred snail-lines derived from individual $B$. nasutus progenitors harvested in the study area. The first two experiments were carried out to determine the time of onset of PCR positivity and its rate. 


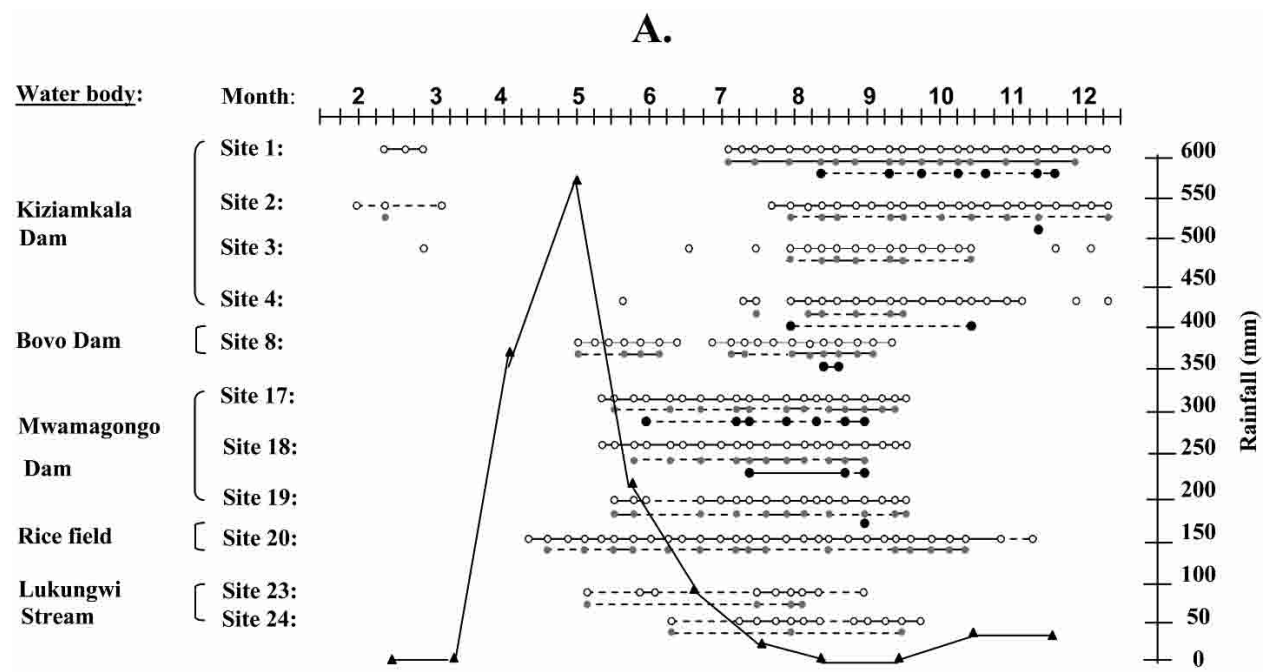

B.

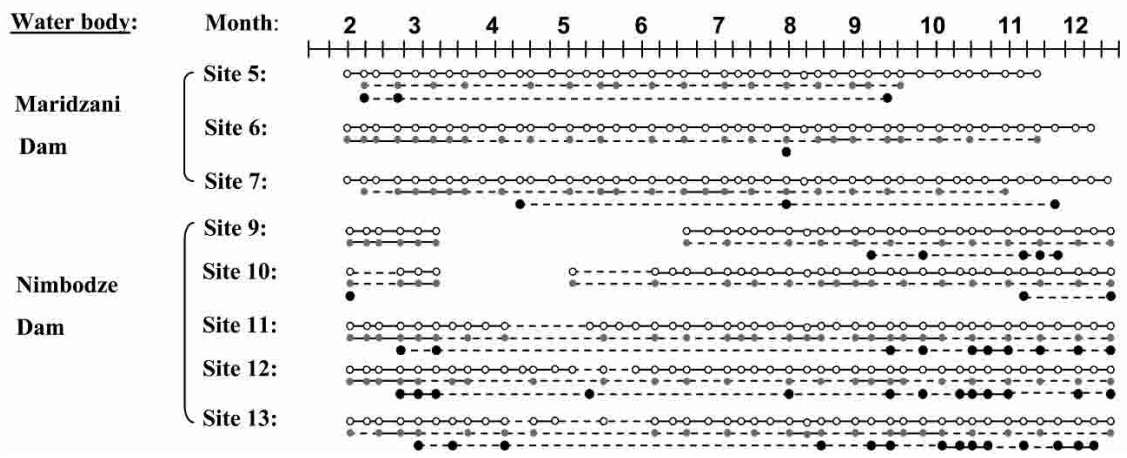

FIGURE 1. Timing of snail detection, prepatent infections, and patent infections at seasonal (temporary) sites $(\mathbf{A})$ and perennial sites $(\mathbf{B})$ in Kenya. Open circles = snails (Bulinus nasutus) collected; gray circles = polymerase chain reaction-positive snails (prepatent infection) found; solid circles $=$ snails shedding cercariae (patent infection) found; broken line $=$ intermittent presence; solid line $=$ continuous presence. A curve of monthly rainfall over time is included (peak rainfall $=568 \mathrm{~mm}$ ).

After 180 or 120 snails were exposed individually to five $S$. haematobium miracidia, samples ( $\leq 20$ snails depending on availability considering natural mortality) were taken at different times after exposure for harvesting DNA and for PCR, and the proportion of snails exhibiting PCR positivity were determined. In one of these experiments, PCR positivity was detected as soon as one day after miracidial exposure, with 4 of the 20 snails tested $(20 \%)$ showing PCR positivity, and 3 days later 11 of the 20 snails tested $(55 \%)$ were PCR positive. The overall PCR positivity rate in this experiment was $32.4 \%$ of the 142 surviving snails from which samples were taken. For those time points providing samples $\geq 10$ snails, the observed PCR positivity rates ranged between $15 \%$ and $55 \%$. In the second experiment, PCR positivity was examined beginning 5 days after exposure to miracidia, when 13 (76.4\%) of 17 exhibited PCR positivity; overall $56.9 \%$ of the 93 surviving snails tested PCR positive. In this second experiment, when those samples $\geq 10$ snails were considered, PCR positivity ranged between $30 \%$ and $84.6 \%$.

In a third experiment, $100 \mathrm{~B}$. nasutus snails were followed from miracidial exposure through patency, and on to death. Their survival curve was compared with that of a concurrent group of unexposed (uninfected) control snails. Figure 3A presents the survival curves of exposed and unexposed snails.
The median survival of exposed laboratory snails was 56 days. The last exposed snail died on day 105, and was, incidentally, a former shedder (Figure 3B). As seen in Figure 3B, the survival of snails after they started shedding cercariae ranged from 4 to 19 days (average $=10.5$ ) in 10 of the 12 shedders, and was 57 and 60 days in the remaining two. In the 9 snails where the last day of shedding was recorded, subsequent survival ranged from 1 to 6 days (average $=2$ ). Unexposed (uninfected) snails lived significantly longer (Figure 3A), with the last dying on day 150 (median survival $=88$ days; $P<$ 0.001 , by log rank test). Any exposed snail, later found dead was also tested for residual S. haematobium infection by PCR.

For the infected-exposed group, the expression of patency was low, amounting to a cumulative rate of $12 \%$ of the total laboratory-infected snails (a total of 12 shedding snails of the 100 exposed). The peak shedding rate was $7 \%$ (5 of 71 surviving snails) in week 7. As shown in Figure 3B, the first onset of patent infection in these B. nasutus was 34 days after exposure to miracidia, but for most captive snails, cercarial shedding began between 42 and 52 days post-exposure. Shedding lasted, continuously or intermittently, for at least 30 days after infection, until day 64 (details on shedding beyond this day are not available). The average duration of the cercarial shedding period in 8 of the 12 shedders was 5.75 days (range 


\section{A. MONTHLY DATA}

Temporary sites: 1-4 (Kiziamkala Dam); 17-19 (Mwamagongo Dam)
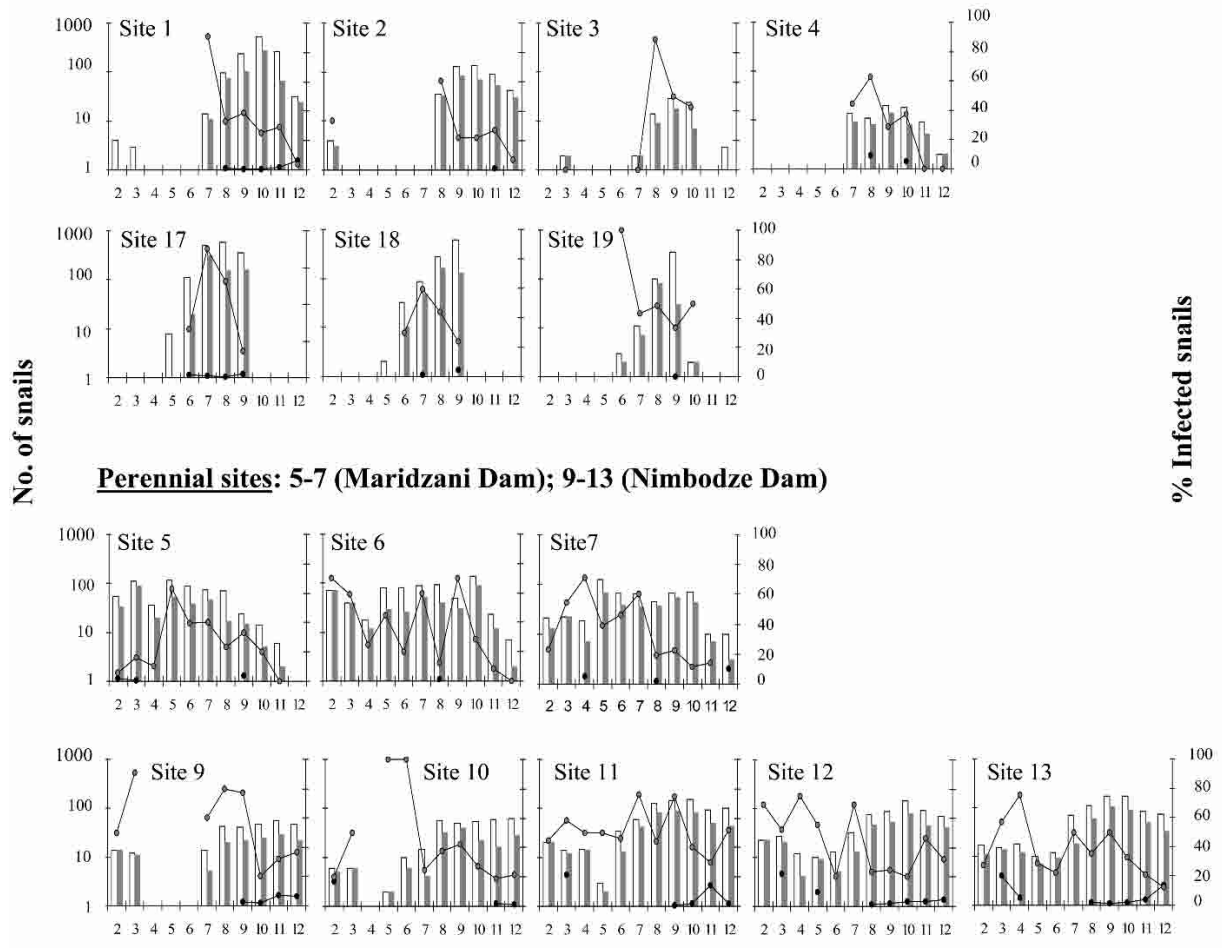

Months

B. OVERALL DATA

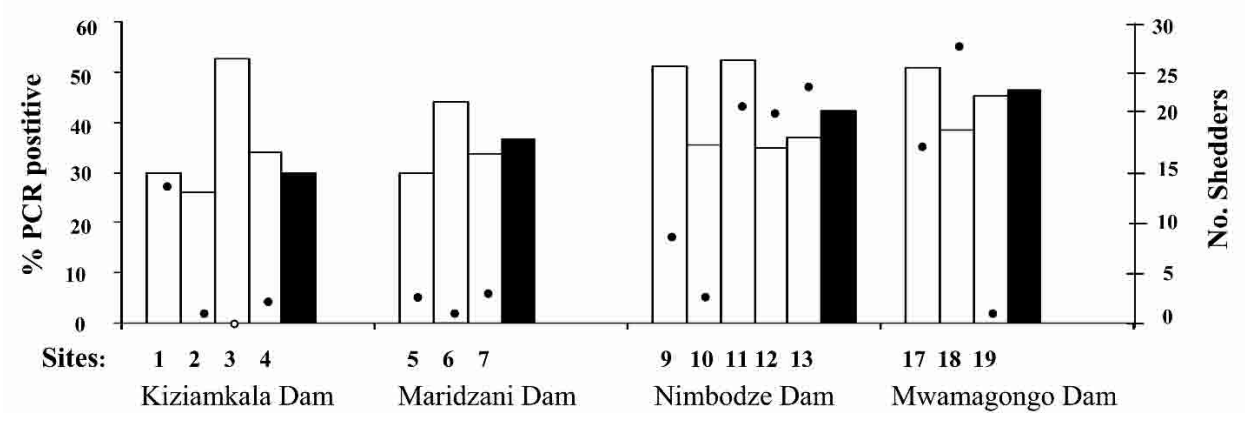

FIGURE 2. Numbers of snails and rates of prepatent and patent infections at the major transmission sites in Kenya. A, Monthly data. Open bars = number of snails collected; gray bars = number of snails taken for a polymerase chain reaction (PCR); gray circles = PCR-positive snails; solid circles = snails shedding cercariae. B, Overall data. Open bars $=\%$ PCR positive per site; solid bars $=$ average PCR positives per water body; solid circles $=$ number of snails shedding cercariae.

=1-12 days), and for 2 of the other 4 shedders it was 18 and $>25$ days, or was not available. The cercariae shed were not counted, but by observation their quantity was low.

The earliest onset of PCR positivity could not be determined in this experiment since samples of live snails were not taken for the PCR. The PCR positivity was detected as soon as the first infected snails were found dead (day 10), and continued until 85 days post-exposure (Figure 3B). The overall PCR positivity rate found in this experiment, as in the second experiment described earlier, was $60 \%$. Since the age/ size of the snails in the laboratory experiments was not recorded, the effect of age on the rate of PCR positivity in the various laboratory experiments could not be determined.
Polymerase chain reaction positivity versus cercarial shedding over time among field snails. For the field-collected snails, PCR positivity was detected very soon after snails appeared at seasonal sites, where the first onset of snail detection and infection could be recorded. As shown in Figure 2A, overall PCR positivity rates in the various sites ranged from $28.3 \%$ to $54.5 \%$ (average $=39.8 \%$ ). Monthly PCR positivity rates ranged between a low of $<10 \%$ (in four monthly samples) and a high of $>90 \%$ (in seven samples), but in the majority of the monthly samples, PCR positivity rates ranged between $11 \%$ and $40 \%$ (in 51 samples) and $41-80 \%$ (in 57 samples). As seen in Figure 2A the lowest and highest PCR positivity rates were usually found when snails first appeared 


\section{A. Survival curve}

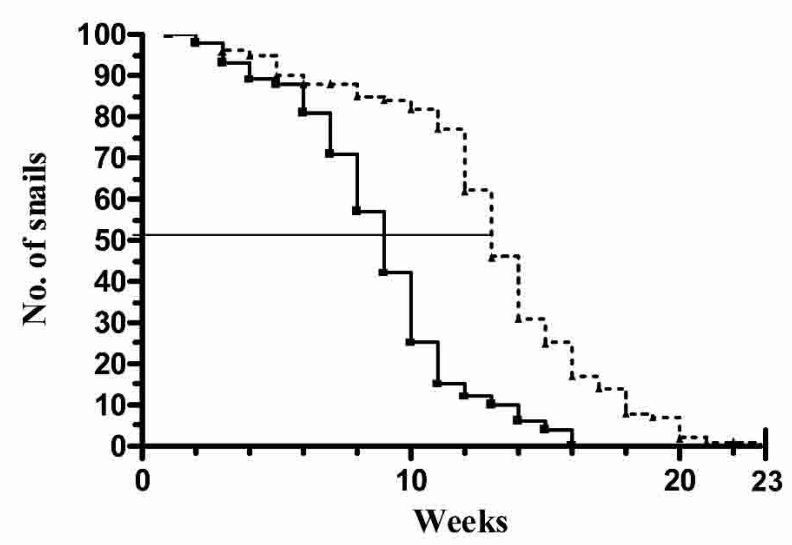

\section{B. Timing of prepatent and patent infection}

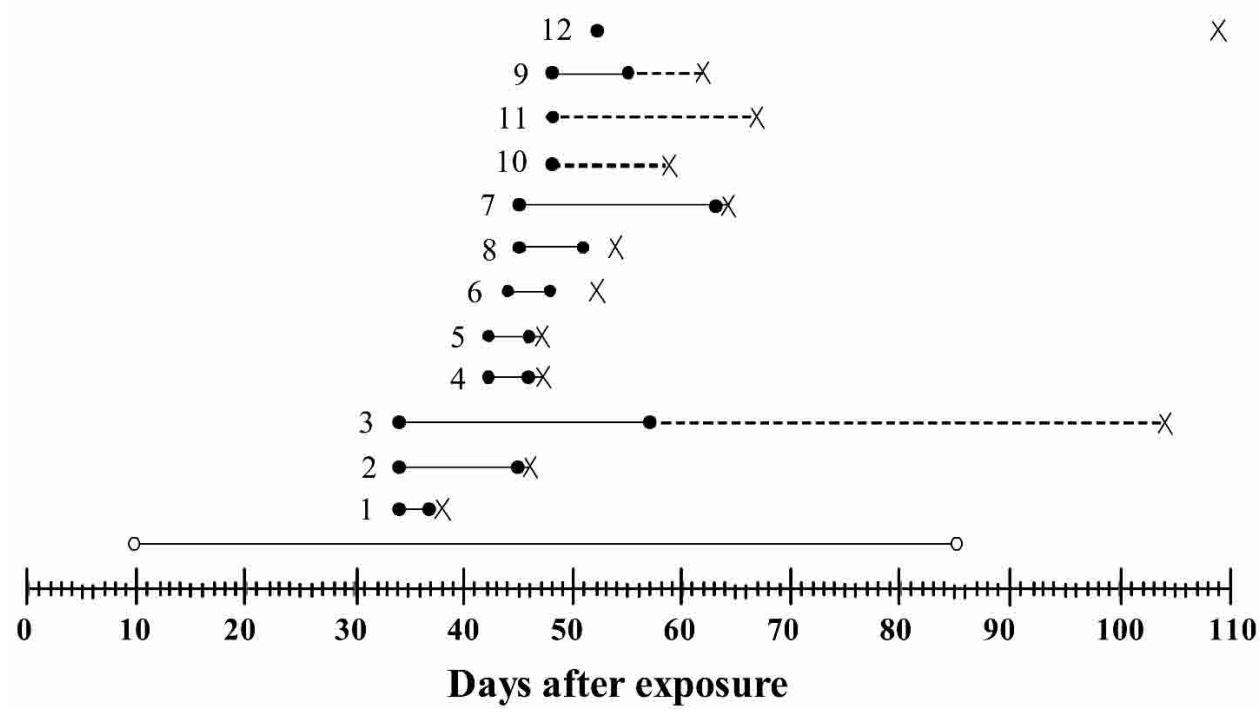

FIGURE 3. Infection of laboratory-reared snails. A, Survival of snails. Solid line = snails exposed to infection; broken line = uninfected control snails. B, Timing of prepatent infection (polymerase chain reaction [PCR] positivity) and patent infection, and survival among 12 individual snails with patent infection (1-12). Open circles = prepatent infection (PCR positivity); solid circles = patent infection; solid lines = duration of infection; broken lines $=$ duration of patent infection unknown; $x=$ time of death.

at a site, or as they disappeared from it (for prolonged termination periods at seasonal sites, or brief ones at perennial sites). The PCR positivity rates varied over time, with curves of PCR-positivity in seasonal (temporary) sites (i.e., sites 1, 2, $3,4,8,17,18,19,20)$ presenting one to three peaks, while in perennial sites (i.e., sites 5, 6, 7, 9-13) several successive peaks of PCR positivity were usually observed (Figure 2A).

Duration of prepatent infection and possible identification of estivating snails. At sites where a clear onset of snail prepatent and subsequent patent infection were observed, the time elapsing between first detection of infected snails (PCRpositive snails) and first detection of shedding snails was believed to estimate the duration of the prepatent period under field conditions. Snails with patent infection appeared in 15 of the 19 sites monitored in the study, ranging between $0.14 \%$ and $3.41 \%$ (mean $=1.56 \%$ ) over the entire study period. In contrast, high prepatent infection rates were found at all sites where host snails were recovered and human contact was observed. As seen in Figure 1, the apparent prepatent period in field snails was 5-6 weeks at sites 1 and 18, respectively, where relatively large numbers of snails with patent infection were ultimately detected ( 14 of 1,186, and 28 of 994, respectively). The time difference between peak number of snails with prepatent infection and peak number of snails with patent infection in all Nimbodze sites combined (sites 9-13) was approximately two months (Figure 4). This value is taken to represent the average duration of the prepatent period in field-captured snails from perennial ponds. At seasonal sites where patent infection appeared approximately three months after the onset of PCR positivity (sites 2 and 19 as seen in Figures 1 and 2A) patent snail numbers were low (only 1-2 snails with patent infection as seen in Figure 2B), making estimation of the prepatent period uncertain.

At sites 4 and 17, shedding (patent) snails were detected as soon as 12 and 10 days after the first detection of prepatent infections (Figure 1). Given the length of the prepatent infec- 


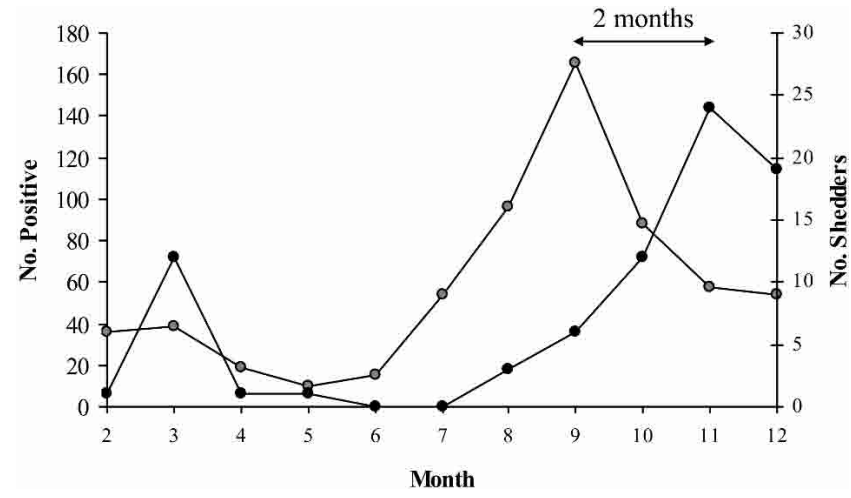

FIGURE 4. Time curves for snails with prepatent (polymerase chain reaction $[\mathrm{PCR}]$ positive; gray circles) and patent (cercarial shedding; solid circles) infections at Nimbodze dam (sites 9-13 combined). The time difference between peak numbers of snails with prepatent and patent infection is indicated.

tion in laboratory-bred and field snails found at other sites, the snails exhibiting this early cercarial shedding were thought to represent estivating snails that had emerged with existing prepatent infection that soon converted to patency.

Lack of a relationship between temporal variability and focality of patent infections to variability in prepatent infection rates. Shedding rates in the various sites ranged $0.14 \%$ to $3.41 \%$ (average $=1.56 \%$ ) and at some sites, shedding snails were entirely absent. At sites 2, 3, 4, 5, 6, 7, 8, 10,19, 20, 23, and 24 , although prepatent $S$. haematobium infection rates were high, as detected by the PCR, only $0-3$ snails with patent infection were ever detected during the whole study period (Figures 1 and 2B). Of the four sites at Kiziamkala dam (sites $1-4)$, only one (site 1) had a stable population of shedding snails (14 snails shedding cercariae were found during August through December, a rate of $1.18 \%$ ), while the other $\mathrm{Ki}$ ziamkala sites (sites 2, 3, and 4) had either no shedding snails or only two snails with patent infection (Figures 1 and 2A). At the same time, detectable prepatent infections were as high or even higher at sites 2,3 , and $4(28.3,52.6 \%$, and $34.8 \%)$, than at site $1(29.8 \%)$. It can be argued that this pattern might be due to the low number of snails found at sites 3 and 4 (74 and 75 , respectively), but at site 2 , many snails (782) were recovered, but only two shedding snails were observed. A similar pattern appeared in sites at Mwamagongo dam. Here, sites 17 and 18 exhibited a relatively stable population of cercarial shedders, while at site 19 , only one shedder was found in the 465 snails collected. Nevertheless, the prepatent infection rate at site 19 was $45 \%$, compared with $38 \%$ and $51 \%$ at sites 17 and 18 , respectively.

Variability in overall PCR positivity rates at the water bodies was also noted when an average PCR positivity was calculated for all sites combined at each water body (Figure 2B). Thus, for the major water bodies closest to human habitation, each with 3-5 well-defined transmission sites, the PCR positivity rates were as follows: $29.9 \%$ at Kiziamkala dam, $36.5 \%$ at Maridzani dam, $42 \%$ at Nimbodze dam, and $46.4 \%$ at Mwamagongo dam.

The PCR positivity rate was also determined in one noncontact site (Vijana Shop dam). Thirty-seven B. nasutus snails were collected from this site during May-June 2001 and only one $(2.7 \%)$ was found to be PCR positive. The possible con- tribution of baboons, also hosts of S. haematobium, to the overall PCR positivity and to the PCR positivity at the nontransmission site was not investigated.

\section{DISCUSSION}

In the present study, for the first time, large-scale monitoring of prepatent schistosomal infection was accomplished in host snails taken from the field, through the use of Dra I-PCR amplifying $S$. haematobium DNA within B. nasutus. The Dra I-PCR assay is group specific for schistosome species with terminal-spined ova, ${ }^{26}$ but is believed to have detected only $S$. haematobium in the present samples, since animal Schistosoma spp. are very rare in this area (Kariuki HC, unpublished data). Schistosoma haematobium-specific primers have recently been developed in our laboratory, and preliminary PCR results on 84 samples confirm the $S$. haematobium identity of the PCR-positive results from our study area (Hoffman $\mathrm{O}$ and others, unpublished data).

The PCR results enabled analysis of the temporal and quantitative relationships between populations of snails having prepatent and patent infections at different types of transmission sites. Seasonal (temporary) sites, with clear onset and termination of snail detection, were found useful for following snail infection from early prepatency, through patency, to the eventual disappearance of infected snails (Figure 1). The timing of events at such sites enabled estimation of the minimal duration of prepatent period to be approximately one month (Figure 1), similar to that determined in laboratoryinfected snails (Figure 3B). The proposed median prepatent infection period was approximately two 2 months, somewhat higher than the median prepatent infection period in laboratory snails (Figure 3B) and similar to the time difference between peak prepatent infection levels and peak patent infections at the Nimbodze dam (sites 9-13 combined, Figure 4). At certain sites, snails with patent infection appeared much sooner (10-12 days after onset of prepatent infections), which is believed to represent the emergence of post-estivation snails carrying prepatent infection which soon developed to patency (Figure 1). Their identification as such still requires formal morphologic evidence not explored in the present study.

Detection of infected snails by PCR, very soon after they have been penetrated by miracidia, has been previously accomplished in laboratory-bred Biomphalaria snails infected with Schistosoma mansoni, ${ }^{25}$ with demonstrated high infection rates reaching $80 \%$. In the present study, very early detection of $S$. haematobium infection was demonstrated in laboratory snails, with approximately $36-60 \%$ overall prepatency rates (see Results). Very early detection of prepatency was subsequently also demonstrated in field snails (Figures 1). The early PCR detection of infected snails, soon after miracidial penetration, implies that the entire prepatent period can be observed with a much higher sensitivity than that found previously for other methods. Serial shedding of snails taken from the field to the laboratory detects only those prepatent infections that eventually culminate in cercarial shedding, but not those in which parasite development is arrested. ${ }^{21}$ Crushing tests, ${ }^{21}$ as well as monoclonal antibodies, ${ }^{22}$ enable identification of prepatent infection only after the primary sporocyst stage, and do not measure prospective cercarial shedding capacity. The high rate of prepatent infections 
among field snails estimated in the present study can be considered realistic given the sensitivity of the detection method and the specific detection of schistosome DNA in the very early stages of infection. The expected longevity of infected snails, and the persistence of PCR positivity within them, as observed in controlled laboratory experiments (Figure 3), further supports this point. The local human population is known to have repeated and intensive water contact in the study area, ${ }^{27}$ which is expected to cause repeated contamination of the sites with schistosome ova. The observed intermittent peaks of prepatent infection (Figure 2A) likely represent the accumulation of waves of prepatent infections through repeated contamination events, alternating with cumulative enhanced mortality of infected snails. In comparison, total snail numbers did not show clear alternating peaks in most sites, and this would be expected where snail population growth rates were as high or slightly higher than mortality rates.

It appears that proper conditions exist for infection by miracidia at all sites where host snails are present and human water contact is known to occur. However, at certain sites, the appearance of snails with patent infection was largely prevented. This focality of patent infection was found even within the same large water bodies (e.g., Kiziamkala dam and Mwamagongo dam, Figures 1 and 2A), and was unrelated to the rate of prepatent infections. Ultimately, the focal presence of shedding (patent) snails, may not be related to rates of contamination, but to a combination of contamination and certain, as yet undefined, environmental conditions. It remains to be determined from our continuing studies whether the absence of shedders is consistent at certain sites (i.e., predictable). Further identification of non-transmitting sites, as well as exploration of the environmental conditions limiting the appearance of snails with patent infection (whether through inhibition of parasite development and/or rapid death of shedders) is now possible by the PCR approach we have developed. Among environmental factors to be considered are salt composition, detergent concentrations, and presence of plants with potential molluscicidal activity. Further exploration may discover other possibilities of control through environmental modification. In this regard, a focused effect on shedders may be sufficient for interruption of transmission, and the timing and duration of such measures should consider the timing and duration of patent infection (Figures 1 and $3 \mathrm{~B}$ ).

In contrast to patency rates, the high PCR positivity rates seem to be unrelated to environmental conditions because PCR-positive snails appeared at all sites where host snails were present and human water contact was known to occur (Figures 1 and 2A). It is therefore suggested that in our study area, PCR positivity rates (prepatency rates) were primarily related to the level of contamination with schistosome ova. This possibility is further suggested by the finding that in a site where no human contact is known to occur, PCR positivity was minimal (perhaps due to egg deposition by baboons, which are known to roam the area). To clarify this point, further examination of PCR positivity will be required at more non-contact sites and for longer periods of time.

Further studies are in progress to determine the association between the high PCR rates, described in the present work, and the levels of infection among people contacting the sites, and its possible implications for implementation of control strategies. Our preliminary data suggest such a correlation, and a full-scale spatial analysis is underway.

The high rate of prepatent infection with S. haematobium, combined with the corresponding low rate of patent infection, suggests that $B$. nasutus in our study area is of lower susceptibility than the bulinids previously tested by standard methods in other areas. ${ }^{13-15}$ Additional studies, with varying schistosome-snail combinations, will be required to determine whether the prepatent:patent infection ratio can serve as a marker of schistosome/snail compatibility.

For practical monitoring in control/eradication programs, the most suitable timing and duration of monitoring have yet to be determined. To facilitate large-scale monitoring, a simplified dot-blot method, with improved cost effectiveness and user-friendliness, might effectively replace the PCR, which cannot be considered practical for field use. Preliminary comparison of the PCR with dot-blotting using a Dra I probe suggests that dot blotting may be a suitable alternative tool for large-scale detection of schistosomal DNA in snails, setting the stage for its use as a practical, large-scale monitoring tool for detection of $S$. haematobium contamination at transmission sites.

Received February 15, 2004. Accepted for publication July 7, 2004.

Acknowledgments: We thank Peter Mungai for his invaluable managerial input, and Anthony Chome, Charles Nganga, Jackson Muinde, Robin Bundi, Idi Masemo, and Joyce Bongo for their invaluable contributions to the field work. Grace Nguma took care of data entry and management. This paper is published with the kind permission of the Director of Medical Services, Ministry of Health, Kenya. Joseph Hamburger wishes to thank Dr. Eli Meir for his assistance in facilitating the summary of the results. Portions of this work were performed in fulfillment of the Ph.D degree of Orit Hoffman.

Financial support: This research was supported by grants from the National Institutes of Health under grants AI-45473 (National Institute of Allergy and Infectious Diseases) and TW/ES01543 (Fogarty International Center).

Authors' addresses: Joseph Hamburger and Orit Hoffman, Department of Parasitology, The Kuvin Center for the Study of Infectious and Tropical Diseases, Hebrew University of Jerusalem, Hadassah Medical School, PO Box 12272, Jerusalem, 91120, Israel, Telephone: 972-2-675-8082, Fax: 972-2-6757425, E-mails: hambu@cc.huji.ac.il and orirh@md2.huji.ac.il. H. Curtis Kariuki and Eric M. Muchiri, Ministry of Health, PO Box 20750, Nairobi, Kenya, Telephone: 254-20-725833, Fax: 254-20-720030, E-mail: schisto@wananchi.com. John H. Ouma and Davy K. Koech, Kenya Medical Research Institute, Mbagathi Road, Nairobi, Kenya, Telephone: 254-20-722541, Fax: 254-20720030, E-mails: ouma@wananchi.com and dkoech@kemri.org. Robert F. Sturrock, 92 Brennard Road, Dongara, WA6525, Western Australia, Australia, Telephone: 61-08-9927-1556, E-mail: sturrock@ iprimus.com.au. Charles H. King, Center for Global Health and Diseases, Wolstein 4126, Case Western Reserve University School of Medicine, 10900 Euclid Avenue, Cleveland, OH 44106-7286, Telephone: 216-368-4818, Fax: 216-368-4825, E-mail: chk@po.cwru.edu.

\section{REFERENCES}

1. King CH, 2001. Epidemiology of schistosomiasis: determinants of transmission of infection. Mahmoud AAF, ed. Schistosomiasis. London: Imperial College Press, 115-132.

2. Vercruysse J, Shaw DJ, de Bont J, 2001. Index of potential contamination for schistosomiasis. Trends Parasitol 17: 256-261.

3. Barbour AD, 1985. The importance of age and water contact patterns in relation to Schistosoma haematobium infection. Trans R Soc Trop Med Hyg 79: 151-153.

4. Chandiwana SK, Woolhouse ME, 1991. Heterogeneities in water contact patterns and the epidemiology of Schistosoma haematobium. Parasitology 103: 363-370. 
5. Sturrock RF, Klumpp RK, Ouma JH, Butterworth AE, Fulford AJ, Kariuki HC, Thiongo FW, Koech D, 1994. Observations on the effects of different chemotherapy strategies on the transmission of Schistosoma mansoni in Machakos District, Kenya, measured by long-term snail sampling and cercariometry. Parasitology 109: 443-453.

6. Sturrock RF, Diaw OT, Talla I, Niang M, Piau JP, Capron A, 2001. Seasonality in the transmission of schistosomiasis and in populations of its snail intermediate hosts in and around a sugar irrigation scheme at Richard Toll, Senegal. Parasitology 123 (Suppl): S77-S89.

7. Ouma JH, Sturrock RF, Klumpp RK, Kariuki HC, 1989. A comparative evaluation of snail sampling and cercariometry to detect Schistosoma mansoni transmission in a large-scale, longitudinal field-study in Machakos, Kenya. Parasitology 99: 349-355.

8. Sturrock RF, 2001. The schistosomes and their intermediate hosts. Mahmoud AAF, ed. Schistosomiasis. London: Imperial College Press, 7-83.

9. Anderson RM, May RM, 1979. Prevalence of schistosome infections within molluscan populations: observed patterns and theoretical predictions. Parasitology 79: 63-94.

10. Barbour AD, 1996. Modeling the transmission of schistosomiasis: an introductory view. Am J Trop Med Hyg 55 (Suppl): 135-143.

11. Gryseels B, 1996. Uncertainties in the epidemiology and control of schistosomiasis. Am J Trop Med Hyg 55 (Suppl): 103-108.

12. Donnelly FA, Appleton CC, Schutte CH, 1983. The influence of salinity on certain aspects of the biology of Bulinus (Physopsis) africanus. Int J Parasitol 13: 539-545.

13. Joubert PH, Pretorius SJ, Kruger FJ, 1991. Further studies on the susceptibility of Bulinus africanus to infection with Schistosoma haematobium. Ann Trop Med Parasitol 85: 253-258.

14. Gracio MA, 1988. A comparative laboratory study of Bulinus (Physopsis) globosus uninfected and infected with Schistosoma haematobium. Malacol Rev 21: 123-127.

15. Woolhouse ME, 1989. The effect of schistosome infection on the mortality rates of Bulinus globosus and Biomphalaria pfeifferi. Ann Trop Med Parasitol 83: 137-141.

16. Shiff CJ, Evans A, Yiannakis C, Eardley M, 1975. Seasonal influence on the production of Schistosoma haematobium and S. mansoni cercariae in Rhodesia. Int J Parasitol 5: 119-123.

17. Woolhouse ME, Chandiwana SK, 1989. Spatial and temporal heterogeneity in the population dynamics of Bulinus globosus and Biomphalaria pfeifferi and in the epidemiology of their infection with schistosomes. Parasitology 98: 21-34.

18. Fine PE, Lehman JS Jr, 1977. Mathematical models of schistosomiasis: report of a workshop. Am J Trop Med Hyg 26: 500-504.

19. Barbour AD, 1978. Macdonald's model and the transmission of bilharzia. Trans R Soc Trop Med Hyg 72: 6-15.

20. Bradley DJ, May RM, 1978. Consequences of helminth aggregation for the dynamics of schistosomiasis. Trans $R$ Soc Trop Med Hyg 72: 262-273.

21. Sturrock RG, Karamsadkar SJ, Ouma JH, 1979. Schistosome infection rates in field snails: Schistosoma mansoni in Biomphalaria pfeifferi from Kenya. Ann Trop Med Parasitol 73: 369-375.

22. Hamburger J, Weil M, Turetzky T, Ouma JH, Koech DK, Klumpp R, Siongok TK, Sturrock RF, 1989. Identification of snails infected with schistosomes by ELISA employing monoclonal antibodies: Schistosoma mansoni in laboratory snails
(Biomphalaria glabrata) and in field snails (Biomphalaria pfeifferi) from Kenya. Am J Trop Med Hyg 40: 613-619.

23. Hamburger J, Weil M, Anton M, Turetzky T, 1989. Schistosoma mansoni antigens recognized in Biomphalaria glabrata hemolymph by monoclonal antibodies. Am J Trop Med Hyg 40: 605-612.

24. Hamburger J, Turetzky T, Kapeller I, Deresiewicz R, 1991. Highly repeated short DNA sequences in the genome of Schistosoma mansoni recognized by a species-specific probe. Mol Biochem Parasitol 44: 73-80.

25. Hamburger J, He N, Xin XY, Ramzy RM, Jourdane J, Ruppel A, 1998. A polymerase chain reaction assay for detecting snails infected with bilharzia parasites (Schistosoma mansoni) from very early prepatency. Am J Trop Med Hyg 59: 872-876.

26. Hamburger J, He N, Abbasi I, Ramzy RM, Jourdane J, Ruppel A, 2001. Polymerase chain reaction assay based on a highly repeated sequence of Schistosoma haematobium: a potential tool for monitoring schistosome-infested water. Am J Trop Med Hyg 65: 907-911.

27. Muchiri EM, Ouma JH, King CH, 1996. Dynamics and control of Schistosoma haematobium transmission in Kenya: an overview of the Msambweni Project. Am J Trop Med Hyg 55: 127-134.

28. King CH, Lombardi G, Lombardi C, Greenblatt R, Hodder S, Kinyanjui H, Ouma J, Odiambo O, Bryan PJ, Muruka J, Magak P, Weinert D, Mackay W, Ransohoff D, Houser H, Koech D, Siongok TK, Mahmoud AAF, 1988. Chemotherapy-based control of schistosomiasis haematobia. I. Metrifonate versus praziquantel in control of intensity and prevalence of infection. Am J Trop Med Hyg 39: 295-305.

29. el Kholy H, Arap Siongok TK, Koech D, Sturrock RF, Houser H, King CH, Mahmoud AA, 1989. Effects of borehole wells on water utilization in Schistosoma haematobium endemic communities in Coast Province, Kenya. Am J Trop Med Hyg 41 : 212-219.

30. Sturrock RF, Kinyanjui H, Thiongo FW, Tosha S, Ouma JH, King CH, Koech D, Siongok TK, Mahmoud AA, 1990. Chemotherapy-based control of schistosomiasis haematobia. 3. Snail studies monitoring the effect of chemotherapy on transmission in the Msambweni area, Kenya. Trans R Soc Trop Med Hyg 84: 257-261.

31. Kariuki HC, Clennon JA, Brady M, Kitron U, Sturrock RF, Ouma JH, Tosha S, Ndzovhu M, Mungai P, Hamburger J, Hoffman O, Pellegrini C, Muchiri EM, King CH, 2004. Distribution patterns and cercarial shedding of Bulinus nasutus and other snails in Msambweni area, Coast Province, Kenya. Am J Trop Med Hyg 70: 449-456.

32. Olivier L, Schneidermann M, 1956. A method for estimating the density of aquatic snail populations. Exp Parasitol 5: 109-117.

33. Butterworth AE, Dalton PR, Dunne DW, Mugambi M, Ouma JH, Richardson BA, Siongok TK, Sturrock RF, 1984. Immunity after treatment of human schistosomiasis mansoni. I. Study design, pretreatment observations and the results of treatment. Trans R Soc Trop Med Hyg 78: 108-123.

34. Stothard JR, Hughes S, Rollinson D, 1996. Variation within the internal transcribed spacer (ITS) of ribosomal DNA genes of intermediate snail hosts within the genus Bulinus (Gastropoda: Planorbidae). Acta Trop 61: 19-29.

35. Browne HG, Thomas JI, 1963. A method for isolating pure, viable schistosome eggs from host tissues. J Parasitol 49: 371374. 